\title{
Standardization of Vase Solutions for Maximum Buds Opening and Longer Vase-Life of Gladiolus Flower cv. Nova Lux
}

\author{
Navneeshdhar Dwivedi, Bhagwan Deen, Awadhesh Kumar*, \\ Malay Marut Sharma and Anish Kumar Jaiswal
}

Department of Horticulture, College of Horticulture and Forestry, Narendra Deva University of Agriculture and Technology, Narendra Nagar, Faizabad, Uttar Pradesh-224229, India

*Corresponding author

\section{A B S T R A C T}

The experiment of vase solution was standardized for longer vase-life of

Keywords

Gladiolus, Vase-

life, Florets

opening, Sucrose,

Citric acid

Article Info

Accepted:

26 February 2018

Available Online:

10 March 2018 gladiolus flower. In this investigation gladiolus spikes were harvested at basal pair opened bud stage in early morning from the field, thereafter spikes were put into conical flask containing vase solution of different concentration as per treatment in laboratory of Department of Horticulture. The observations were recorded on florets opening, spike weight, vase solution absorption, florets drooping and vase-life at 2 days interval. The maximum 12 days vase-life of flower was obtained with continuous florets opening, spike weight first increased thereafter decreased, absorption of vase solution first increased thereafter decreased and continuous florets drooping, when spikes were kept with $6 \%$ sucrose $+3 \%$ citric acid to be best for maximum florets opening till end of the experiment.

\section{Introduction}

Gladiolus (Gladiolus grandiflorus L.) has been derived from the Latin word gladiolus or gladiator because of its sward like leaves. It has been appropriately crowned as "Queen of Bulbous Flower". The opening of florets in sequence over longer duration makes it to be a good quality of cut flower. The gladiolus is available in fantastic colour range and spikes of almost any colour near black to white, white, pink, yellow and violet, colours are available. The herbaceous plant sprouts from auxiliary buds of an underground modified stem called corm. The corm, a condensed vertical root stock, covered with dried leaf bases. It differs from a bulb in being solid and having no stem. The United State of America is major producer of gladiolus and export 6.5 million gladiolus spikes to Mexico. Whereas the import in the U.S.A. is around 13 million stem per year; Germany produces gladiolus in the open in 74 hectares of land, which is only one per cent of all flowers, consumption in Germany. As regards the aesthetic value of cut flower, the bulbous flowers are very popular 
throughout the world. Bulbous ornamentals constitute one of the most important groups of the floriculture wealth of the country. The beauty, fragrance, wide range of colour and form make them the most attractive group among flowers. Bulbous flowers have become integral part of commercial floriculture. In India the various floricultural activities including flower trade, bedding, plant industry, plant rental services, flower seeds and dry flower industry are running. The changing life style of Indians with a tendency to "say it with flower" and celebration of festivals like Valentine's day, Christmas day, Mather's day has created a tremendous demand of cut flowers like rose, carnation, gerbera, gladiolus, and tuberose. Improvement of keeping quality and enhance the vase-life of cut flowers are important areas in Horticultural research. Sucrose and aluminium sulphate increased cut flower vase-life, by increasing water uptake and maximum florets opening of tuberose flower (Kumar and Deen, 2017).

The vase-life of gladiolus is around 6-7 days under normal condition. Several attempts have been made to study the effect of different chemicals and sugars on the longevity and economic value of cut flowers (Halevy and Mayak, 1979). Several preservatives/chemicals i.e. cobalt sulphate, silver nitrate, 8-HQS, boric acid, ascorbic acid, aluminium sulphate, sucrose, citric acid, etc. have been used in different formulations and combinations to increase the vase-life of gladiolus Saini et al., (1994), Reddy and Singh (1996) and Sathyanarayana et al., (1996). Flower remains fresh longer if they are placed in a suitable floral preservative (Nowak and Rudnicki, 1990). Use of floral preservatives is the most economical and practicable method for extending the post-harvest life of cut flowers (Salunkhe et al., 1990). The silver nitrate, STS and some other chemicals have been banned for flower preservative because they are unhealthy and pollutants for environment therefore, search for another combination of preservative is required for vase solution. Therefore, finding pertaining to extend the vase-life of cut flowers by the chemical treatments after harvest has been made with varying success.

\section{Materials and Methods}

The standardization of vase solution for longer vase-life of gladiolus flower cv. Nova Lux was conducted at post graduate laboratory of Department of Horticulture, N. D. University of Agriculture and Technology, Narendra Nagar Faizabad (U.P.), India during the year 2014-2015. The spikes were procured from gladiolus field at Main Experiment Station of Department of Horticulture. The site falls under subtropical climate is geographically situated at $26.47{ }^{0} \mathrm{~N}$ latitude, $82.12{ }^{0} \mathrm{E}$ longitude and 113 meter altitude. The spikes were harvested at basal pair opened bud stage in morning by sharp knife and brought to laboratory into bucket containing distilled water. In laboratory $3 \mathrm{~cm}$ lower portion of the spikes were removed by making slanting cut thereafter spikes were put treatment wise in to vase containing $200 \mathrm{~mL}$ vase solution as per treatments i.e. $\mathrm{T}_{1}$ - Distilled water, $\mathrm{T}_{2}-3 \%$ sucrose, $\mathrm{T}_{3}-6 \%$ sucrose, $\mathrm{T}_{4}-3 \%$ citric acid, $\mathrm{T}_{5}-6 \%$ citric acid, $\mathrm{T}_{6}-3 \%$ sucrose $+3 \%$ citric acid, $\mathrm{T}_{7}-6 \%$ sucrose $+6 \%$ citric acid, $\mathrm{T}_{8}-3 \%$ sucrose $+6 \%$ citric acid and $\mathrm{T}_{9}-6 \%$ sucrose $+3 \%$ citric acid and observations were recorded at room temperature on opening of florets, fresh weight of spike, absorption of vase solution, drooping of florets and vase-life of flower and observations were recorded at 2 days intervals.

\section{Statistical analysis}

The research was conducted with 3 replications in Completely Randomized Design during vase-life study of cut flower. 
The collected data were analyzed to find out the 5 per cent level of significant (Panse and Sukhatme, 1985)

\section{Results and Discussion}

\section{Opening of florets}

Data recorded was furnished in Table 1, showed that florets opening was started from $2^{\text {nd }}$ day of observation to end of the investigation. The maximum opening of florets was recorded with $6 \%$ sucrose $+6 \%$ citric acid. Whereas opening was stopped after $10^{\text {th }}$ day of observation in all treatments this might be due to absorption of higher amount of vase solution that facilitated to more uptake of sucrose. Waithika et al., (2001) also reported that opening of gladiolus florets was accompanied by carbohydrate concentration. Similar observations were also reported by Halevy (1987) in carnation.

\section{Spike weight}

Data recorded on spike weight during vase-life study are presented in Table 2 . The maximum decreasing trend of weight of spike was recorded on $10^{\text {th }}$ day of observations when spikes put in vase solution containing 6\% sucrose $+3 \%$ citric acid. Decrease in spike of weight might be due to decrease in water relation parameters. Beside, the second peak (climacteric rise) in the respiratory drift, which is considered to decide final senescence stage (Swarup, 1993). Similarly, Stimart (1983) found that weight of zinnia spike gradually increased of fresh weight thereafter it was decreased with increase the period of observations day.

\section{Vase solution absorption}

The absorption of vase solution in all treatment including control was increased up to $4^{\text {th }}$ day of observation, thereafter it was decreased with study period showed in Table 3 . The lesser absorption of vase solution on $10^{\text {th }}$ day of observation in comparison to $T_{1}$, $\mathrm{T}_{2}, \mathrm{~T}_{3}, \mathrm{~T}_{4}, \mathrm{~T}_{5}$ and $\mathrm{T}_{6}$ treatments.

The lesser absorption of vase solution might be because of the sucrose let to slight decrease in the water uptake by the stems, because sucrose and citric acid are also known to cause closer of stomata leading to reduction in water loss (Halevy and Mayak, 1981). Similar results reported with Ali et al., (2008) in cut daffodil flower, who found that vase solution as distilled water uptake was first increased thereafter decrease sharply after $6^{\text {th }}$ day of observation.

Table.1 Effect of vase solution on opening of florets

\begin{tabular}{|c|c|c|c|c|c|}
\hline \multirow[t]{2}{*}{ Vase solution } & \multicolumn{5}{|c|}{ Opening of florets (\%) } \\
\hline & $2^{\text {nd }}$ day & $4^{\text {th }}$ day & $6^{\text {th }}$ day & $8^{\text {th }}$ day & $10^{\text {th }}$ day \\
\hline$T_{1}$ Distilled water (control) & 30.40 & 50.70 & 56.10 & 60.30 & 68.00 \\
\hline $\mathrm{T}_{2} 3 \%$ sucrose & 35.80 & 55.60 & 73.30 & 85.20 & 85.20 \\
\hline $\mathrm{T}_{3} 6 \%$ sucrose & 37.50 & 59.30 & 74.10 & 85.50 & 85.50 \\
\hline $\mathrm{T}_{4} 3 \%$ citric acid & 33.90 & 54.50 & 72.90 & 83.90 & 85.10 \\
\hline $\mathrm{T}_{5} 6 \%$ citric acid & 32.60 & 54.10 & 71.10 & 83.60 & 84.90 \\
\hline $\mathrm{T}_{6} 3 \%$ sucrose $+3 \%$ citric acid & 32.30 & 48.50 & 64.70 & 83.80 & 84.30 \\
\hline$T_{7} 6 \%$ sucrose $+6 \%$ citric acid & 35.70 & 51.30 & 68.70 & 85.10 & 96.50 \\
\hline $\mathrm{T}_{8} 3 \%$ sucrose $+6 \%$ citric acid & 34.30 & 52.80 & 67.20 & 84.10 & 86.90 \\
\hline$T_{9} 6 \%$ sucrose $+3 \%$ citric acid & 43.20 & 59.40 & 68.10 & 84.00 & 91.90 \\
\hline SEm \pm & 3.41 & 4.18 & 4.74 & 5.13 & 5.23 \\
\hline CD at $5 \%$ & 7.17 & 8.79 & 9.97 & 10.78 & 10.99 \\
\hline
\end{tabular}


Table.2 Effects of vase solutions on weight of spike

\begin{tabular}{|l|} 
Vase solutions \\
\hline $\mathrm{T}_{1}$ Distilled water (control) \\
\hline $\mathrm{T}_{2} 3 \%$ sucrose \\
\hline $\mathrm{T}_{3} 6 \%$ sucrose \\
\hline $\mathrm{T}_{4} 3 \%$ citric acid \\
\hline $\mathrm{T}_{5} 6 \%$ citric acid \\
\hline $\mathrm{T}_{6} 3 \%$ sucrose $+3 \%$ citric acid \\
\hline $\mathrm{T}_{7} 6 \%$ sucrose $+6 \%$ citric acid \\
\hline $\mathrm{T}_{8} 3 \%$ sucrose $+6 \%$ citric acid \\
\hline $\mathrm{T}_{9} 6 \%$ sucrose $+3 \%$ citric acid \\
\hline $\mathrm{SEm} \pm$ \\
\hline $\mathrm{CD}$ at $5 \%$ \\
\hline
\end{tabular}

\begin{tabular}{|l|l|l|l|l|}
\hline \multicolumn{5}{|c}{ Spike weight $(\mathrm{g})$} \\
\hline $2^{\text {nd }}$ day & $4^{\text {th }}$ day & $6^{\text {th }}$ day & $8^{\text {th }}$ day & $10^{\text {th }}$ day \\
\hline 40.60 & 47.80 & 44.10 & 32.13 & 17.50 \\
\hline 53.00 & 54.40 & 49.00 & 35.80 & 20.30 \\
\hline 62.10 & 73.10 & 65.80 & 48.00 & 30.20 \\
\hline 49.90 & 59.50 & 92.90 & 36.00 & 30.80 \\
\hline 38.80 & 45.70 & 42.00 & 30.60 & 19.20 \\
\hline 64.90 & 76.50 & 77.10 & 57.40 & 32.30 \\
\hline 56.00 & 77.80 & 70.00 & 51.10 & 32.40 \\
\hline 68.80 & 80.90 & 74.40 & 54.30 & 34.20 \\
\hline 73.50 & 86.60 & 77.90 & 58.80 & 35.70 \\
\hline 8.07 & 4.50 & 4.28 & 3.68 & 3.02 \\
\hline 8.56 & 9.45 & 9.00 & 4.74 & 6.34 \\
\hline
\end{tabular}

Table.3 Effects of vase solutions on absorption of vase solution

\begin{tabular}{|l|}
\hline Vase solutions \\
\hline $\mathrm{T}_{1}$ Distilled water (control) \\
\hline $\mathrm{T}_{2} 3 \%$ sucrose \\
\hline $\mathrm{T}_{3} 6 \%$ sucrose \\
\hline $\mathrm{T}_{4} 3 \%$ citric acid \\
\hline $\mathrm{T}_{5} 6 \%$ citric acid \\
\hline $\mathrm{T}_{6} 3 \%$ sucrose $+3 \%$ citric acid \\
\hline $\mathrm{T}_{7} 6 \%$ sucrose $+6 \%$ citric acid \\
\hline $\mathrm{T}_{8} 3 \%$ sucrose $+6 \%$ citric acid \\
\hline $\mathrm{T}_{9} 6 \%$ sucrose $+3 \%$ citric acid \\
\hline $\mathrm{SE} m \pm$ \\
\hline $\mathrm{CD}$ at $5 \%$ \\
\hline
\end{tabular}

\begin{tabular}{|l|l|l|l|l|}
\hline \multicolumn{5}{|c|}{ Absorption of vase solution (mL) } \\
\hline $2^{\text {nd }}$ day & $4^{\text {th }}$ day & $6^{\text {th }}$ day & $8^{\text {th }}$ day & $10^{\text {th }}$ day \\
\hline 20.70 & 24.50 & 22.96 & 22.10 & 16.00 \\
\hline 25.10 & 27.20 & 26.10 & 25.50 & 22.10 \\
\hline 27.50 & 30.40 & 29.70 & 28.80 & 25.10 \\
\hline 26.50 & 30.10 & 29.10 & 28.40 & 26.50 \\
\hline 25.10 & 29.80 & 28.50 & 28.10 & 25.40 \\
\hline 27.50 & 31.10 & 27.50 & 26.90 & 25.60 \\
\hline 29.40 & 32.50 & 28.10 & 27.50 & 24.80 \\
\hline 28.10 & 29.40 & 27.60 & 26.80 & 23.10 \\
\hline 28.80 & 30.50 & 27.90 & 26.10 & 23.80 \\
\hline 3.05 & 3.22 & 3.13 & 3.10 & 2.97 \\
\hline 6.41 & 6.77 & 6.59 & 6.53 & 6.24 \\
\hline
\end{tabular}

Table.4 Effects of vase solutions on drooping of florets

\begin{tabular}{|l|}
\hline Vase solutions \\
\hline$T_{1}$ Distilled water (control) \\
\hline $\mathrm{T}_{2} 3 \%$ sucrose \\
\hline $\mathrm{T}_{3} 6 \%$ sucrose \\
\hline $\mathrm{T}_{4} 3 \%$ citric acid \\
\hline $\mathrm{T}_{5} 6 \%$ citric acid \\
\hline $\mathrm{T}_{6} 3 \%$ sucrose $+3 \%$ citric acid \\
\hline $\mathrm{T}_{7} 6 \%$ sucrose $+6 \%$ citric acid \\
\hline $\mathrm{T}_{8} 3 \%$ sucrose $+6 \%$ citric acid \\
\hline $\mathrm{T}_{9} 6 \%$ sucrose $+3 \%$ citric acid \\
\hline SEm \pm \\
\hline CD at $5 \%$ \\
\hline
\end{tabular}

\begin{tabular}{|c|c|c|c|c|}
\hline \multicolumn{5}{|c|}{ Drooping of florets $(\%)$} \\
$2^{\text {nd }}$ day & $4^{\text {th }}$ day & $6^{\text {th }}$ day & $8^{\text {th }}$ day & $10^{\text {th }}$ day \\
\hline 0 & 0 & 22.20 & 55.60 & 77.80 \\
\hline 0 & 0 & 14.80 & 48.10 & 59.30 \\
\hline 0 & 0 & 14.40 & 34.80 & 50.20 \\
\hline 0 & 0 & 10.70 & 28.90 & 50.40 \\
\hline 0 & 0 & 19.20 & 39.70 & 52.80 \\
\hline 0 & 0 & 16.00 & 32.30 & 45.90 \\
\hline 0 & 0 & 10.00 & 22.60 & 41.30 \\
\hline 0 & 0 & 7.90 & 21.00 & 36.90 \\
\hline 0 & 0 & 10.70 & 21.40 & 37.60 \\
\hline- & - & 2.31 & 3.26 & 3.97 \\
\hline- & - & 4.85 & 6.85 & 8.33 \\
\hline
\end{tabular}


Table.5 Effects of vase solutions on vase-life of gladiolus spike

\begin{tabular}{|l|c|}
\hline \multicolumn{1}{|c|}{ Vase solutions } & Vase-life in days \\
\hline $\mathrm{T}_{1}$ Distilled water (control) & 6.30 \\
\hline $\mathrm{T}_{2} \mathbf{3} \%$ sucrose & 8.50 \\
\hline $\mathrm{T}_{3} 6 \%$ sucrose & 10.70 \\
\hline $\mathrm{T}_{4} \mathbf{3} \%$ citric acid & 8.20 \\
\hline $\mathrm{T}_{5} \mathbf{6 \%}$ citric acid & 8.45 \\
\hline $\mathrm{T}_{6} \mathbf{3} \%$ sucrose $+3 \%$ citric acid & 9.00 \\
\hline $\mathrm{T}_{7} \mathbf{6 \%}$ sucrose + 6\% citric acid & 9.50 \\
\hline $\mathrm{T}_{8} \mathbf{3} \%$ sucrose + 6\% citric acid & 9.35 \\
\hline $\mathrm{T}_{9} \mathbf{6 \%}$ sucrose + 3\% citric acid & 11.90 \\
\hline SEm & 2.01 \\
\hline $\mathrm{CD}$ at 5\% & 4.22 \\
\hline
\end{tabular}

\section{Drooping of florets}

Data with respect to drooping of florets in Table 4, reveals that drooping of florets was increased with increasing the study period. The drooping of florets was stared from $4^{\text {th }}$ day of observation to end of the experiment. The drooping was increased with a period that was because of senescence which is obvious after cutting the spike. The minimum $(36.90 \%)$ drooping was observed on $10^{\text {th }}$ day of observation with $6 \%$ sucrose $+3 \%$ citric acid followed by $37.60 \%$ with $3 \%$ sucrose + $6 \%$ citric acid but there was no significant difference between these two treatments that might be because of higher per cent of sucrose into these treatments that provide necessary carbon and respiratory substrate to release energy required for florets opening. Kumar and Deen (2017) reported that tuberose spike was put in to $3 \%$ sucrose +100 ppm aluminium sulphate, minimum drooping was recorded on termination of the experiment.

\section{Vase-life}

The data as embodied in Table 5, clearly reflected that the maximum (12 days) vaselife was recorded with $6 \%$ sucrose $+3 \%$ citric acid followed 11 days with $6 \%$ sucrose. The higher concentration of sucrose found maximum vase-life that might be due to sucrose act as a carbon source, maintains mitochondrial structure (Halevy and Mayak, 1981, Kaur et al., 2006) that might be the reason for longer vase-life of gladiolus spikes. The findings are in agreement with Kumar and Deen (2017) who reported flower spike was kept with 5\% sucrose and $100 \mathrm{ppm}$ aluminium sulphate provide 12 days vase-life of tuberose spike. These reports are in support of present findings.

It can be concluded from the above investigation the maximum 12 days vase-life of gladiolus could be achieved by putting spikes in to conical flask with vase solution containing 6\% sucrose and 3\% citric acid fallowed by 11 days vase-life of flower could be achieved by vase solution containing $6 \%$ sucrose.

\section{References}

Ali, S., Khan, F.U., Khan, F.A. and Wani, S.A. 2008. Post-harvest behavior of cut daffodil as influenced by certain pulsing treatment. Journal of Ornamental Horticulture, 11(2):81-90. 
Halevy, A.H. 1987. Recent advances on postharvest physiology of carnation. Acta Horticulture, 216: 216-221.

Halevy, A.H. and Mayak, S. 1979. Senescence and post-harvest physiology of cut flowers. Part 1 Horticulture Reviews, 1: 204-236.

Halevy, A.H. and Mayak, S. 1981. Senescence and post-harvest physiology of cut flowers. Part 2 Horticulture Reviews, 3: 59-143.

Kaur, G., Singh, P. and Parmar, V. 2006. Change in sugar metabolism in gladiolus tritis during senescence as affected by ethylene and its antagonists. Journal of Plant Science Research, 22: 81-89.

Kumar, A. and Deen, B. 2017. Effect of ecofriendly vase solution on maximum buds opening and longer vase-life of tuberose (Polianthes tuberosa L.) cv. Hyderabad Double. Journal of Pharmacognosy and Phytochemistry, 6(4): 1233-1236.

Nowak, J. and Rudnicki, R.M. 1990. Postharvest handling and storage of cut flowers, florist green and potted plants. Chapman and Hall London, New York, Tokyo. Melbovrne. Madras. Chapter. 2 and $b .417-512$.

Panse, V.G. and Sukhatme, P.V. 1985. Statistical methods for agricultural works $5^{\text {th }}$ Ed. ICAR, New Delhi, 147157.

Reddy, B.S. and Singh, K. 1996. Effect of aluminium sulphate and sucrose on vase-life of tuberose. Journal of Maharashtra Agriculture University, 21(2): 201-203.

Saini, R.S., Yamdagni, R. and Sharma, S.K. 1994. Effect of different chemicals on vase-life of cut tuberose. South Indian Horticulture, 42: 376-412.

Salunkhe, D.K., Bhat, N.R. and Desai, B.B. 1990. Post-harvest biotechnology of flowers and ornamental plants. Springer-Verlag, Berlin, 349-412.

Sathyanarayana, R.B., Singh, K., Singh, A. and Saini, A. 1996. Advances in Agricultural Research in India. Indian Horticulture, 4: 39-45.

Stimart, P. 1983. Effect of physiological factors of flower zinia. Journal of Ornamental Horticulture, 1(1): 18-26.

Swarup, V. 1993. Floriculture industry in India. Journal of Ornamental Horticulture, 1(1): 19-26.

Waithika, K., Dodge, L.L. and Reid, S.S. 2001. Carbohydrate traffic during opening of gladiolus florets. Journal of Horticulture Science and Biotechnology, 76: 120-125.

\section{How to cite this article:}

Navneeshdhar Dwivedi, Bhagwan Deen, Awadhesh Kumar, Malay Marut Sharma and Anish Kumar Jaiswal. 2018. Standardization of Vase Solutions for Maximum Buds Opening and Longer Vase-Life of Gladiolus Flower cv. Nova Lux. Int.J.Curr.Microbiol.App.Sci. 7(03): 3145-3150. doi: https://doi.org/10.20546/ijcmas.2018.703.363 